\title{
ECOFEMINISM AND ENVIRONMENTAL SECURITY
}

\author{
UDC 502/504:305-055.2
}

\author{
Ana Batrićević ${ }^{1}$, Nikola Paunović ${ }^{2}$ \\ ${ }^{1}$ Institute of Criminological and Sociological Research, Belgrade, Republic of Serbia \\ ${ }^{2}$ Ministry of Foreign Affairs of the Republic of Serbia
}

\begin{abstract}
Having in mind climate change as well as the rising risk of potential environmental crisis caused by pollution and unsustainable exploitation of natural resources, the concept of environmental security, primarily defined as the resilience of countries and individuals to the challenges of environmental degradation, is rapidly obtaining the interest of general public and experts from various scientific disciplines. However, it seems that the gender aspect of security in general and particularly of environmental security has not been given the amount of attention it deserves until recently. Thanks to the ecofeminist movement, based on the idea that women are more closely related to nature than men and more vulnerable and susceptible to the negative impacts of environmental degradation (especially those emerging as the consequences of pollution and climate change), the role of women in the improvement of environmental security through participation in decision-making processes in legislation and public policy making is finally being recognised. The aim of this paper is to analyse the modern concept of environmental security as well as the evolution and contemporary discourses within ecofeminist movements and to explain the link between them, i.e., the contribution of ecofeminism to the shift in the approach to environmental security in the sense of taking into consideration the rights and interests of women as more common victims of negative environmental impacts as well as their potentials as relevant stake holders in this field.
\end{abstract}

Key words: ecofeminism, environment, ecology, security, environmental security

\section{INTRODUCTION}

The ecologically destructive nature of the modern world is becoming increasingly exposed and challenged due to a broader scientific and social recognition of numerous environmental problems (Barnett, 2001: 1). The literature linking the environment and security suggests two main approaches in the context of combating environmental problems: Environmental security and Ecological security. Environmental security is influenced by the discussions of

Received May $15^{\text {th }}, 2019 /$ Accepted May $28^{\text {th }}, 2019$

Corresponding author: Ana Batrićević, PhD, Senior Research Fellow; Institute of Criminological and Sociological Research, 18 Gračanička Street, Belgrade, Republic of Serbia; E-mail: a.batricevic@yahoo.com 
human security. Ecological security, by contrast, refers to those analyses which focus on the negative impacts that human behaviours have on the environment (Cudworth, Hobden, 2011: 43-45). Research shows that both environmental and ecological security risks endanger women more severely than men for several reasons. In 1994, the United Nations stated that in no society are women secure or treated equally to men; thereby from childhood through adulthood, they are abused because of their gender (United Nations Development Programme, 1994: 31). Unfortunately, more than two decades later, the situation regarding women's vulnerability and susceptibility to negative environmental impacts (particularly those emerging due to climate change) has remained more or less the same. What seems to be improving, however, is the recognition and the affirmation of the crucial role that women play in environmental protection, ecological development and sustainable use of natural resources. In order to address the growing challenge of the women security, it is now indisputable that a new paradigm is necessary that would put them at the centre of development. It is also recognised that little can be achieved without a dramatic improvement in the status of women and opening of all economic opportunities to women. From that point of view, it should be noted that sustainable development empowers women, by enabling them to design and participate in the processes of the protection of natural systems on which all life depends (United Nations Development Programme, 1994: 4).

Several factors seem to have contributed to this improvement, including the growing ecofeminist movement whose impacts are more and more notable in the media, various scientific debates, social, economic and environmental policies, legislative documents, etc. The Ecofeminist schools have claimed a global connection between women as a gender and nature, in order to save the environment. There are currently two main versions of ecofeminism. According to the essentialist ecofeminism framework, women are programmed to nurture and empathize with the fertile natural world. This essentialist perspective is opposed by constructionist ecofeminism, which states that gender is socially constructed, claiming that women's relationship to nature is constructed in specific social contexts. In other words, according to this approach, the alliance between women and nature has been socially constructed as an aspect of patriarchal power. In that sense, women activate their support for nature in public political action by struggling to achieve environmental goals (Leahy, 2003:106-107). Bearing in mind the link that exists between environmental security and ecofeminism, this paper analyses the concepts of environmental security and ecofeminism. The main goal of this paper is to demonstrate the importance of ecofeminist approaches in the context of the concept of environmental security.

\section{ENVIRONMENTAL SECURITY}

The term "environmental security" refers to a relative resilience of the public to ecological hazards caused by natural or human actions (Bakrač, Vuruna, Milanović, 2010: 315). Defining environmental security seems to be rather difficult because there is no common agreement on the issue that this term is supposed to address. In the 1970s and 1980 s, the research was predominantly oriented towards redefining the concept of security so that the term security could encompass both newly emerged risks and the standpoint according to which the object of security is not only the state but the individual as well. During the 1990s, several empirical case studies were conducted, focusing on the interaction between the factors of global changes, environmental degradation, scarcity of natural resources, and the impacts that these factors have on conflicts or cooperation between 
the states. At the end of the $20^{\text {th }}$ century, research on environmental security tackled the issue of potential conflict due to the use of resources, failures of the states to prevent these conflicts, and the syndromes of global changes (Jovanović Popović, 2013: 105).

It appears that the best way to explain the essence of environmental security is to recognise the link between environmental degradation and security in general (Barnett, 2001:6), as well as the relationship between environmental degradation and environmental insecurity. Environmental degradation is best described as the process by which the lifesustaining functions of the biosphere are disturbed. As such, it includes the totality of a series of interdependent processes occurring at a range of scales and in different places to differing degrees. These processes comprise, inter alia, atmospheric pollution and climate change, biodiversity loss, soil loss, salinization and acidification of soils and water, fisheries depletion, depletion of forests and timber, marine pollution and contamination of plants and animals by synthetic chemicals and radioactive substances (Barnett, 2001:14). The application of new technologies and methods in industry and agriculture increases the risk of environmental degradation and introduces a series of new challenges in the area of protection, particularly in cases where safety standards and procedures regarding ecological security and protection are violated (Beriša, Jegeš, Slavković, 2015: 727).

Regardless of its cause, environmental degradation represents a serious threat to human security and all life on Earth. Air and water pollution, deforestation, soil erosion (etc.), resulting from civilian and military activities can and do change our living conditions dramatically (Graeger, 1996: 109). Hence, environmental insecurity can be defined as the vulnerability of people to the effects of environmental degradation. This implies that environmental insecurity represents more than just a physical process of environmental degradation. On the contrary, it includes the way this degradation affects the welfare of human beings. Therefore, environmental insecurity should be perceived as social problem, both in terms of the way it impacts human welfare and because the meta-problem of environmental degradation emerges as a product of human behaviour (Barnett, 2001: 17).

The end of the Cold War and increasing knowledge on the harmful impacts of environmental degradation have intensified the efforts to find a more comprehensive security concept in the scientific, political and military community; thus, "security is increasingly being defined as the security of individuals as human beings as such, and not only as citizens of a particular state" (Graeger, 1996: 109). In accordance with the aforementioned standpoint, the entire human environment is being taken into consideration in order to preserve security, including the need to resolve environmental issues and guarantee a sustainable future (Graeger, 1996: 109).

Environmental degradation or change may emerge as both the causes and the consequences of violent conflicts. Namely, it seems that environmental degradation as well as insufficient respect for sustainable management of natural resources may lead to disputes within countries and between otherwise friendly countries (Graeger, 1996: 110). When environmental degradation is a consequence of international acts of warfare, it often escalates the conflict (Graeger, 1996: 110). All armed conflicts and acts of terrorism produce a series of negative direct or indirect impacts on the environment (Batrićević, Paunović, 2018:69). For example, massive pollution of air, water and soil and the devastation of flora and fauna were evidenced during World War II (particularly after two atomic bombs were dropped on Japan), during armed conflicts in Cambodia, Vietnam, Afghanistan and Kuwait as well as during the NATO bombing of the Republic of Serbia in 1999 (Mannion, 2003: 5-6).

Regardless of its cause, there is no doubt that environmental degradation leads to environmental insecurity in the broadest sense. For example, it has been proven that 
climate change (as one of the most severe consequences of environmental degradation) has several implications for human security, especially given its wide-ranging impacts on critical livelihood sectors and communities with the least capacity to adapt (Denton, 2011: 21). There are two principal ways of understanding the problem of environmental insecurity: as national security threats arising from environmental degradation, or as human impacts on the security of the environment itself. Environmental insecurity is considered to be a way in which environmental degradation threatens the security of people, with a particular focus on the various impacts of environmental degradation on different groups of people. In this sense, this approach to environmental insecurity is also related to the theories of environmental justice (Barnett, 2001: 12).

Predictability and control are essential elements of military security considerations, which are also important elements in safeguarding the environment, and there seems to be a "conceptual kinship which makes it natural to speak of security in both connections" (Lodgard, 1990: 17). Therefore, under certain circumstances, irreparable environmental degradation or ecological systems in dramatic change may boost the probability of escalation of violent conflicts (Graeger, 1996: 110). Lodgard's definition of environmental security includes not only sustainable utilisation and protection of the environment but also the minimisation of risk, or rather - of the probability for experiencing negative consequences of environmental change (Lodgard, 1992: 20). This, in turn, may be related to industrial activities and technology where there is a potential for major damage to the environment (Graeger, 1996: 110). The concept of sustainable development is primarily oriented towards the improvement of the quality of life, including: economic development (accomplished through continuous economic growth without inflation and increase in debt), social development (embodied in the elimination of poverty and all kinds of social pathology), and ecological development (based on rational use of natural resources and environmental protection) (Beriša et al., 2015: 767). These "three major divisions of sustainability (social equity, economic welfare, environmental quality)" (Banaité, 2016: 149) and components of sustainable development are closely interrelated (Duran, Gogan, Artene, Duran, 2015: 809-810), and they need to coexist in order to remain stable. The concept of sustainable development dwells upon the demand for the maintenance of all natural resources as well as human and physical capital (Beriša et al., 2015: 767). Therefore, the increase of incomes must not be derived from the degradation of natural resources. Quite the reverse, there must constantly exist a balance between the use of resources and the ability of the natural systems to satisfy the needs of the future generations (Beriša et al., 2015: 767-768). On the other hand, the ecological crisis is manifested through the imbalance of environmental factors and the impairing of the unity of the natural and social components, which threaten the stable functioning of the biosphere and the society. So, in the modern world, the disruption of environmental balance caused by unsustainable use of natural resources threatens the survival of both natural and human-made systems (Beriša et al., 2015: 768). In other words, failing to follow the principles of sustainable development is directly linked to environmental degradation and, as such, should also be observed as a factor of environmental insecurity, whereas sustainable development should be perceived as a factor that contributes to environmental security.

\section{ECOFEMINISM}

Ecofeminism represents both an ecological philosophy and a social movement that draws on environmental studies, critiques of modernity and science, and feminist critical 
analyses and activism that is aimed to explicate the links that exist between women and nature, and the implications of these links for environmental politics (Allison, 2017). Being an ecological philosophy and a social movement, ecofeminism embodies a multifaceted critique of global environmental politics. In contrast to mainstream approaches to global environmental politics, which are focused on the role of the nation state or institutions in global, collective efforts to protect and manage the natural environment, feminist critiques emphasize the contextualized experiences of women in politics (Allison, 2017). Ecofeminism examines these experiences specifically as they pertain to nature and the natural environment, especially the daily practices and environmental activism of women living in industrializing nations (Allison, 2017).

Ecofeminism was originally associated with the view that women and nature are connected in morally significant ways because both are identified with femininity. This femininity, associated with characteristics ranging from fecundity to vulnerability to wildness, was seen as a source of ecological and social flourishing that is violently degraded in patriarchal cultures. Ecofeminists took women and nature to be connected because, as providers of life, sustenance and creativity, they are similarly important and valuable, and their strengths are similarly controlled or violated by men (or "patriarchy"). Therefore, ecofeminists advocated turning toward nature and reclaiming the connection, in order to protect the interests of the natural world and to empower women physically, spiritually, and economically (Cuomo, 2002:7). On the one hand, it appears that this standpoint confirms that women have always been connected with nature. In this context, "woman" is referred to as a "unitary concept and reality", focused on the role that women play as "mothers and nurturers of life", regardless of the disparities that might appear between them emerging from factors such as ethnic background, social class and age. On the other hand, it is argued that the biological features of women, that come from the characteristics of their body and its functions (including: pregnancy, childbirth, lactation, menstruation etc.), or cultural experiences (the care and bringing up of children), give them a special natural mindset (Nieves Rico, 1998:22).

In the context of ecofeminist movements, it should be noted that there are three conceptual approaches discussing how ecofeminists have precisely defined the connection between women and nature. First of all, there are conceptual connections between women and nature. The majority of ecofeminists following this standpoint agree with radical feminists when it comes to identifying Western patriarchy as the main cause of ecological destruction on the global level. Their claim is supported by the fact that women are in charge of sustaining human life and they have a feeling of compassion toward their environment, which urges them to conserve and repair it. Second, there are historical connections between women and nature. In this regard, some researchers have found these historical links in the Greek philosophy and the traditions of rationalism. On the other hand, more contemporary historical analyses focus on the scientific revolutions of the $16^{\text {th }}$ and $17^{\text {th }}$ century. These scholars claim that this has accompanied the period of "reductionist and mechanistic science", which triggered unconstrained expansion of industrial development and put women in a subordinated position. Finally, there are spiritual connections between women and nature. These ecofeminists argue that there are some biological features of women that enable them to unlock the mysteries of nature. In that sense, scholars introduce the idea that, at an ideological level, women are closer to nature and more in touch with their bodies, emotions and the natural world; thus, the so called "spiritual ecofeminists" emphasize the internal links between women and the environment (Sapra, 2017: 4-8). 
On the other hand, there are two prominent theoretical schools explaining the materialist conceptions of the connection between women and the environment: 1) feminist environmentalism, and 2) feminist political ecology. Feminist environmentalism is based upon the material concepts of the relationship between gender and environment and their links with some ideological standpoints. Feminist political ecology is focused on the seminal work in the area of feminist environmentalism, with particular spotlight on the issues such as: gendered knowledge, the access to resources and their control as well as the connection between the issues on local and global level. What these conceptions have in common is the standpoint according to which there is no inherent or native link between women on one side and the environment on the other. It would be more appropriate to say that they claim that the relationship between women and nature dwells upon the fact that women have the responsibility for nurturing the land and collecting the products from forests, which is especially present in the global South. Another characteristic that these conceptions have in common is their effort to explore in an intersectional manner the ways in which gender, class, and race impact people's lives. Namely, they explore the gender implications of the separation of work and knowledge/science and practice on the gendered science of survival in rural and industrial contexts through a variety of cases of political and environmental struggle. These conceptions also highlight that men frequently have more access to agro-forestry extension work and knowledge associated with science, whereas women have experiential knowledge obtained through providing household subsistence (Sapra, 2017: 8-12).

The theme of gendered environmental rights and responsibilities examines various political backgrounds in which women are deprived of having the control and rights over natural resources. Finally, gendered environmental politics and grassroots activism focus on exploring the environmental movements and gives particular attention to the role of women. Gendered environmental politics and grassroots activism emphasize the empowerment of women through their efforts to change the environment and global economic processes, as well as the international and national shifts in sustainable development policies that came as the result of their efforts (Sapra, 2017: 8-12). One of the most prominent movements related to the ecofeminists is the Earth democracy, explained by Vandana Shiva as the ancient principle that includes peace, justice and sustainability, which connects the individual with the universal, different and usual, local with global (Ćorić, 2014: 555).

Ecofeminism seems to be a combined product of both ecological movement and women's movement. As such, it entails not only the theoretical essences of feminism but also the theoretical standpoints of ecologism. In the context of its feminist origin, ecofeminism predominantly represents the sublimation of radical, cultural, and socialist feminism. Radical feminism emerged in the 1960s and it is based on the conception of the supremacy of women's reproductive function, with the focus on the relationship, caring and loving culture. In other words, it seems that the feminism theory utilises the conception of patriarchy to clarify female issues. Cultural feminism emerged in the late 1970s and it represents a mixture of Liberal and Socialism feminism, which advocates that it is social culture that constructs social gender. The link between cultural feminism and ecofeminism stems from the fact that ecofeminism also considers that nature and women are products of social culture construction. Finally, Socialist feminism was initiated in the 1970s and it could be described as a combination of the standpoints of Marxist ideology and Radical Feminism. Socialist Feminism had a significant influence on ecofeminism in its "economic analysis approach". From this perspective, "ecofeminism is the development of feminism in the economic-ecological dimension" (Ling, 2014:105-106). 
When it comes to the ecological origin of ecofeminism, it is important to mention that ecofeminism has adopted the latest theoretical standpoints of ecology movements that could be described as radical, such as Deep Ecology and Social Ecology. Emerging in the 1960s, Deep Ecology defends the standpoint that ecological crisis has profound philosophical roots. In that context, Deep Ecology is directed towards a personal and cultural transformation, suggesting the use of holism and denying the anthropocentric approach. Ecofeminism accepts Deep Ecology's approach to exploring the profound reason of ecological crisis. However, it appears that the most transparent difference between these two conceptions refers to the population issue. To be more exact, Deep Ecology considers overpopulation as the main reason for ecological crisis and implies that ecological crisis actually represents a crisis of overpopulation. Therefore, according to Deep Ecology, population growth has to be stopped. For its part, ecofeminism claims that population reduction may be accomplished only via the suppression of male power structure and its technology as well as through the control of women's fertility. By contrast, Social Ecology is focused on the social dimension, blaming hierarchy for all disasters, which indicates that there are at least two sides: the dominant one and the subordinate one. In that context, Social Ecology points out that "the nature's getting rid of human domination relies on the premise of human being out of domination" (Ling, 2014:106). The second one is that Social Ecology permits humans to lead natural evolution since their rationality and society emerged as the results of evolution. However, Ecofeminism raises criticism on Social Ecology, pointing out that Social Ecology expands the term of "domination" from "human domination over humanity to human domination over nature, which not only ignores human domination on nature but it also ignores the differences and characteristics of human domination between non-hierarchical humans" (Ling, 2014:106).

Finally, different conceptual and methodological approaches dealing with the womengender-environment interrelationship should not only include the ecofeminist movements but also the schools discussing women and the environment as well as gender, the environment and sustainable development (Nieves Rico, 1998:21). Ecofeminism has had a significant impact on the school women and the environment, especially when it comes to the assumption that women have a special relationship with nature and that they are devoted to combating environmental degradation. This approach is focused on the specific features of women as guardians of the environment but it seems to be overseeing two facts: 1) that poor women living in developing countries are the victims of severe exploitation, which dramatically harms their health; and 2) that women have a subordinated position in the society due to the distribution of power between genders. On the other side, the initial position of the school gender, environment and sustainable development stems from the fact that women are affected by discrimination that appears in several cases: 1) the genderbased division of labour, which means that women are almost always responsible for household and children; 2) unequal access to productive resources and the benefits of these between men and women; 3) limited participation of women in decision-making processes and access to public power. The differences between women can be identified by emphasizing the social, historical and cultural nature of the processes of subordination and negotiation in which they are involved and through the principles of gender, the environment and sustainable development. Therefore, it should be concluded that the relationships that women have with the environment are shaped by their lifestyles, physical location and social structure as well as by the interrelation of gender systems, class and ethnicity. Moreover, these relationships are modified for individual women throughout their lives. To conclude, this standpoint puts gender relationships against the actual background of countries and regions, 
considering the political economy of the current development situation and how this impacts the gender system and the environment; it also focuses on how the negative impacts of environmental damage predominantly affect women (Nieves Rico, 1998:23-26).

\section{THE IMPORTANCE OF ECOFEMINISM FOR ENVIRONMENTAL SECURITY}

The modern feminist and environmental movements emerged during the same decade, and both came to the critical developmental stage in the 1980s. Their mutual impact was briefly explored in the 1990s (Malone, 2015: 1446). Post-modern ecofeminism urged for essential reconsidering of the role that women have been playing in environmental preservation on global, national and local levels (Malone, 2015: 1446). Namely, ecofeminist movements take into account that women significantly contribute to successful adaptation to changing natural conditions. They do so through their "critical knowledge, experience, agency and unique role in agriculture, food security, livelihoods, income generation, management of households and natural resources in diverse eco-systems, and participation in a variety of socio-cultural, political-economic and environmental institutions" (Nellemann, et al., 2011: 7). On the other hand, they also highlight the fact that women seem to have rather subordinate positions in numerous countries, which will further be discussed in details.

Therefore, the ecofeminist movements are important for establishing social and environmental justice and gender equality, since they take into consideration the subordinate position that women have in many societies across the world, which puts them into a more difficult position in the cases of environmental degradation. Even when both men and women's access to education, health care, political action and financial autonomy is severely restricted, it seems that the subordinate position of women in the social stratification leaves them with the least access to these services and freedoms and sometimes subjects them to physical abuse (Goldsworthy, 2009: 219). Moreover, it appears that there is a social order designed to keep women in the margins of society, creating persistent structural threats to their security by exclusion. The structural position of women in a society can directly and indirectly threaten their livelihoods through violence and discrimination, beginning as early as childhood (Goldsworthy, 2009: 219).

Women are the primary victims of environmental degradation, and in particular the destruction of forests (Ćorić, 2014: 555). It seems that women who live in the Southern areas are particularly susceptible to the negative consequences of disasters since the power relations and inequitable cultural and social norms are a part of tradition in these regions. At the same time, women have a crucial role in the development of sustainable adaptation options because they have the knowledge, responsibilities and important roles in productive areas, such as: agriculture, rangelands, biodiversity conservation, forests, households, income-generation, livelihoods and other socio-cultural and political-economic institutions and relations. It is estimated that women are $43 \%$ of the work force in agriculture worldwide. However, this proportion is higher in Asia and Africa, often exceeding 50\%, particularly in mountain regions. Therefore, women have an essential role when it comes to the attempts to adapt to environmental challenges, to develop and maintain environmental sustainability and food security (Nellemann et al., 2011: 6).

Due to a lack of access to formal education, economic poverty, discrimination in food distribution, food insecurity, limited access to resources, exclusion from policy and decision-making institutions and processes and other forms of social marginalisation, the adaptation is more difficult for some women. It seems that women in general tend to have 
less access to and less control over the vital resources, as well as fewer opportunities to participate in the decision-making processes that affect them. In many contexts, women tend to face gender-based violence, various forms of harassment and psychological violence within the household. These problems have negative impacts on women and restrain their capability to adapt to extreme environmental changes (Nellemann et al., 2011: 6). When natural disasters are concerned, climate change seems to be aggravating the aforementioned discriminatory models, making women even more vulnerable to natural disasters and reducing their life expectancy, particularly if they are in a financially subordinated position (Crowley, 2011: 20). Namely, in extreme natural disasters (such as severe floods and drought), women seem to be facing extra risks; mostly because of gender inequities, they carry a much heavier burden of disaster impacts (Nellemann et al., 2011: 6).

There seems to be another serious risk for women associated with environmental problems: organised trafficking. Although environmental and trafficking issues may not at first glance seem to be link, the reality is different. Namely, natural disasters (flood, drought and famine) that appear as the results of climate changes may interrupt safety nets on the local level. It means that women and children may be left without protection due to the collapse of regular control mechanisms, which makes them particularly exposed to the risk of becoming victims of human trafficking. Actually, it seems that all natural disasters resulting in physical, social or economic instability, affect women and children more severely than men and increase the risk of their victimisation from trafficking (Nellemann et al., 2011: 7).

Women on the verge of poverty are more substantially affected by successive natural disasters because such women have very few financial, land or other resources. Poor women are exposed to a greater risk of losing the minimal safeguard they have, for which reason they often face indebtedness, inequality and poverty. In some countries, climate change encourages men (and sometimes women) to migrate in order to find employment. This increases the amount of work that has to be done by the women that are left behind, especially when it comes to agricultural and domestic obligations (Crowley, 2011: 20).

Ecofeminism is important for environmental security due to the fact it connects the vision of female liberation, social inequalities and, ultimately, social justice with the affirmation of degraded areas and subordinate non-human nature. That is the reason why the promotion of ecofeminist ethics should be interpreted in a broader context - as the promotion of freedom from the dualisms of Western intellectual thought and male-gender bias about women and nature (Ćorić, 2014: 555). Moreover, ecofeminism brings new energy and changes the perspective on environmental issues by giving the true importance to the roles of women and nature. That is the main reason for further development of this ethical conception and also for its implementation in the real life solutions (Ćorić, 2014: 556).

One of the fields where ecofeminist ethics should be applied is the area of sustainable development. Namely, feminist scholars criticised the concept of sustainable development by claiming that it had failed, from an ecofeminist standpoint, to sufficiently deal with the marginalization that women and the poor are facing in developing countries (Malone, 2015: 1457). According to this viewpoint, the concept of sustainable development is still based on the so-called male-centered or androcentric standpoints, which perceive human beings as being separate from nature and above it (Malone, 2015: 1457).

The International Conference on Population and Development (1994) (United Nations, 1995; see also: Shaw, 2007: 321-327), the Beijing Declaration and Platform for Action (1995) (United Nations, 1995a), the World Summit on Sustainable Development (2002) (United Nations, 2002), and the 2005 World Summit (United Nations, 2005) recognized the essential role women play in sustainable development. In its recent follow-up to the Beijing 
Platform for Action, the General Assembly highlighted the need to "involve women actively in environmental decision-making at all levels; integrate gender concerns and perspectives in policies and programmes for sustainable development; and strengthen or establish mechanisms at the national, regional and international levels to assess the impacts of development and environmental policies on women" (A/C.3/62/L.89). ${ }^{1}$

In November 2009, a consultation on the impact of climate change on women and gender relations was sponsored by the United Nations Environment Program and United Nations Foundation. In 2010, the World Bank joined the discourse with its publication "Social Dimensions of Climate Change: Equity and Vulnerability in a Warming World.'(Malone, 2015: 1458). By 2010, the calls for women's involvement in high-stakes climate change policy-making and discourse were having an effect (Malone, 2015: 1459). Notably, women in some European countries seem to show stronger support for their governments' climateprotection policies than men. They also seem to express greater support for more ambitious reduction goals and expect their countries and the European Union to take a principle role in environmental protection (Hemmanti, Röhr, 2009: 155).

\section{CONCLUSION}

Solving environmental problems may promote cooperation and it may be used for security policy or peace building. Thus, environmental security can be perceived as a link between the environment and human activities (Brock, 1991: 407). In that context, ecofeminist movements can have a crucial role in designing ecological and security policies aimed at environment conservation, sustainable development, environmental, social and gender justice.

The impact of ecofeminism, insisting on taking into consideration gender aspects in public policies, is most visible in the area of climate change policies. There seem to be two key reasons why gender considerations should be included in the development of policies tackling climate change issues. The first refers to the presumption that gender mainstreaming in this area has the potential to enhance the results of climate-change combating process. The second is based upon the standpoint that, if gender issues are not considered, progress towards reaching gender equity could be endangered (Hemmanti, Röhr, 2009: 156). Generally speaking, considering different viewpoints of various social groups may lead to establishing better measures, mechanisms and solutions that reflect the interests of the powerful and the less influential social groups (Hemmanti, Röhr, 2009: 156), which particularly refers to women and children who are finally given the chance to be heard, due to the efforts of activists inspired by ecofeminism learning.

It is obvious that all relevant stakeholders (including policymakers, non-governmental organisations, and the academic community) should take into consideration the gender aspect of climate change adaptation and influences (Crowley, 2011: 20). Since the majority of environmental issues are related to climate change, this actually implies that gender aspect has to be taken into consideration when discussing all issues related to environmental protection, environmental degradation and, hence, environmental security. In order to avoid the risks and consequences of climate change, women should be placed

\footnotetext{
${ }^{1}$ The $52^{\text {nd }}$ session of the Commission on the Status of Women Interactive expert panel Emerging issues, trends and new approaches to issues affecting the situation of women or equality between women and men "Gender perspectives on climate change" Thursday, 28 February 2008, https://www.un.org/womenwatch/daw/ csw/csw52/issuespapers/Gender\%20and\%20climate\%20change\%20paper\%20final.pdf, 23.04.2019.
} 
in the centre of activities dedicated to resolving climate change issues, not only because of ethical but also because of economic considerations (Crowley, 2011: 20). Considering the gender perspective on climate change in negotiations at the international level may also preclude the potential negative impacts on climate-change measures and mechanisms on gender equality (Hemmanti, Röhr, 2009: 157).

Women and nature are the key assets that the existence of future generations rests upon. Yet, they are constantly under threat and their existence, according to the representatives of ecofeminism, is on the edge of viability. Under international conventions, countries are bound to change their environmental policies but the adopted policies largely remain black letter on paper, and the mass destruction of nature in the name of people continues (Ćorić, 2014: 556). For this reason, ecofeminist approach should be taken into account when discussing future environmental policies and women should participate as relevant stakeholders in the decision-making processes related to environmental issues, particularly in those pertaining to sustainable development.

\section{REFERENCES}

Allison, J., (2017). Ecofeminism and Global Environmental Politics. Oxford Research Encyclopedia of International Studies, accessed on 22 April 2019, available at http://oxfordre.com/internationalstudies/ view/10.1093/acrefore/9780190846626.001.0001/acrefore-9780190846626-e-158

Bakrač, S., Vuruna, M., Milanović, M., (2010). Degradacija životne sredine - uticaj na ekološku bezbednost, Vojno delo, Vol. 62, No. 3., 2010, pp. 314-328.

Banaite, D. (2016) Towards Circular Economy: Analysis of Indicators in the Context of Sustainable Development, Social Transformations in Contemporary Society, No. 4, 2016, pp. 142-150.

Barnett, J., (2001). The Meaning of Environmental Security: Ecological Politics and Policy in the New Security Era. Zed Books, London.

Batrićević. A., Paunović, N., (2018). Ekološki terorizam - Viktimološki aspekti i mehanizmi prevencije, Temida, Vol. 21, No. 1, 2018, pp. 67-89.

Beriša, H., Jegeš, M., Slavković, R., (2015). Novi bezbednosni izazovi sa aspekta ekološke zaštite, Tehnikakvalitet ims, standardizacija i metrologija, Vol. 15., No. 4., 2015., pp. 727-734.

Brock, L., (1991). Peace through Parks: The Environment on the Peace Research Agenda. Journal of Peace Research, Vol. 28., No. 4., 1991, pp. 407-423.

Crowley, E., (2011). Gender and climate change, In: Nellemann, C., Verma, R., and Hislop, L. (eds), Women at the frontline of climate change: Gender risks and hopes. A Rapid Response Assessment. Arendal, United Nations Environment Programme, p. 20, Retrieved on 24 April 2019 fron http://www.zaragoza.es/ contenidos/medioambiente/onu/1207-eng.pdf

Cudworth, E., Hobden, S., (2011). Beyond environmental security: complex systems, multiple inequalities and environmental risks. Environmental Politics, Vol. 20, No. 1, pp. 42-59.

Cuomo, C., (2002). On Ecofeminist Philosophy. Ethics \& The Environment, Vol. 7 No.2, pp.1-11.

Ćorić, D., (2014). Ecofeminism as a way of resolving some environmental issues, Zbornik Matice srpske za drustvene nauke, Vol. 148., No. 3, pp. 551-558.

Denton, F. (2011) Climate change and gender-Are we downplaying social vulnerability? In: Nellemann, C., Verma, R., Hislop, L. (eds), Women at the frontline of climate change: Gender risks and hopes. A Rapid Response Assessment. Arendal, UN Environment Programme, p. 21, Retrieved from http://www.zaragoza.es/contenidos/medioambiente/onu/1207-eng.pdf 24.04.2019)

Duran,D.C., Gogan, L.M., Artene, A., Duran, V. (2015). The Components of Sustainable Development - A Possible Approach, Procedia Economics and Finance,Vol. 26., pp. 806-811.

Graeger, N., (1996). Environmental Security?, Journal of Peace Research, Vol. 33., No. 1., 1996, pp. 109-116.

Hemmanti, M., Röhr, U. (2009). Engendering the Climate Change Negotiations: Experiences, Challenges and Steps Forward. In: Terry, G. (ed.), Climate Change and Gender Justice. Oxford, Oxfam, pp. 155-168.

Jovanović Popović, D., (2013). Environment and security: The concept of ecological and environmental security, Zbornik Matice srpske za drustvene nauke.Vol. 142., No.1., 2013, pp. 103-

Ling, C., (2014). The Background and Theoretical Origin of Ecofeminism. Cross-Cultural Communication Vol. 10, No. 4, 2014, pp. 104-108. 
Leahy, T., (2003). Ecofeminism in Theory and Practice: Women's Responses to Environmental Issues. Journal of 1111 erdisciplinary Gender Studies Vol. 7 No. 1 \& 2, pp. 106-125.

Lodgaard, S., (1990). Environmental Conflict Resolution, paper presented at the UNEP meeting on Environmental Conflict Resolution in Nairobi, 30.03.1990.

Lodgaard, S., (1992). Environment, Confidance - Building and Security. In Lodgard, S. and Hjort, A. (eds.), The Environment and International Security. Oslo, PRIO-Report No. 3, pp. 19-30 .

Mannion, A., (2003). The Environmental Impact of War and Terrorism, Geographical Paper No.169, Retrieved on 24 April 2019 from https://www.reading.ac.uk/web/files/geographyandenvironmentalscience/GP169.pdf

Malone, L.A., (2015). Environmental Justice Reimagined Through Human Security and Post-Modern Ecological Feminism: A Neglected Perspective on Climate Change, Faculty Publications, Retrieved 24 April 2019 from https://scholarship.law.wm.edu/facpubs/1789

Nellemann, C., Verma, R., Hislop, L. (eds). (2011). Women at the frontline of climate change: Gender risks and hopes. A Rapid Response Assessment. UN Environment Programme, GRID-Arendal. Retrieved 30 04.2019from http://www.zaragoza.es/contenidos/medioambiente/onu/1207-eng.pdf

Nieves Rico, M. (1998). Gender, The Environment And The Sustainability Of Development. United Nations, Santiago, Chile.

Sapra, S. (2017). Feminist Perspectives on the Environment. Oxford Research Encyclopedia of International Studies, Retrieved om 30 04. 2019 from http://oxfordre.com/internationalstudies/view/10.1093/ acrefore/9780190846626.001.0001/acrefore-9780190846626-e-49

Shaw D.J. (2007). International Conference on Population and Development, 1994. In: World Food Security. Palgrave Macmillan, London, pp. 321-327.

The Secretary-General Report on overview of UN activities in relation to climate change A/62/644, Retrieved from https://unstats.un.org/unsd/climate_change/docs/SG_report.pdf ,24.04. 2019

United Nations Development Programme. (1994). Human Development Report 1994. Oxford University Press, New York.

United Nations (1995). Report of the International Conference on Population and Development Cairo, 5-13 September 1994, A/CONF.171113/Rev., United Nations, New York, Retrieved from https://www.un.org/ en/development/desa/population/events/pdf/expert/27/SupportingDocuments/A_CONF.171_13_Rev.1.pdf, 1 May 2019.

United Nations (1995a). Beijing Declaration and Platform of Action, adopted at the Fourth World Conference on Women, 27 October 1995, Retrieved on 1 May 2019 from https://www.refworld.org/docid/3dde04324.html.

United Nations (2002). A/C.2/57/L.83 - World Summit on Sustainable Development, Retrieved from https://www.un.org/ga/search/view_doc.asp?symbol=A/C.2/57/L.83\&Lang=E, 1 May, 2019,

United Nations (2005). Resolution A/RES/60/1 adopted by the General Assembly on 16 Sept. 2005, Retrieved on 1 May 2019 from https://www.un.org/en/development/desa/population/migration/generalassembly/docs/ globalcompact/A_RES_60_1.pdf.

UN Women Watch (2009): Women, Gender Equality and Climate Change, UN WomenWatch, 2009, https://www.un.org/womenwatch/feature/climate_change/\#1, (accessed 24 April 2019).

\section{EKOFEMINIZAM I EKOLOŠKA BEZBEDNOST}

U kontekstu klimatskih promena i rastućeg rizika od ekološke krize izazvane zagađenjem i nedrživim eksploatisanjem prirodnih resursa, koncept ekološke bezbednosti, prvenstveno određen kao spremnost država i pojedinaca da se suoče sa izazovima degradacije životne sredine ubrzano pobuđuje interesovanje kako šire javnosti tako i eksperata iz različitih naučnih disciplina. Međutim, čini se da rodnom aspektu bezbednosti uopšte, a posebno ekološke bezbednosti, sve do nedavno nije pruženo oniliko pažnje koliko zaslužuje. Zahvaljujući ekofeminističkim pokretima, koji počivaju na ideji da su žene više povezane sa prirodom nego muškarci te da su u tom smislu ranjivije i podložnije negativnim uticajima degradacije životne sredine (posebno onim koji se pojavljuju kao posledice zagađenja $i$ klimatskih promenama), uloga žena u unapređenju ekološke bezbednosti kroz njihovo učešće u procesima donošenja odluka u oblasti zakonodavstva i javnih politika konačno je prepoznata. Cilj ovog rada jeste da analizira moderni koncept ekološke bezbednosti, kao i evoluciju i savremene diskurse u okviru ekofeminističkih pokreta, kao i da objasni njihovu povezanos, odnosno doprinos ekofeminizma promeni u pristupu ekološkoj bezbednosti u pravcu uvažavanja prava i interesa žena kao češćih žrtava negativnih ekoloških uticaja ali i njihovih potencijala kao relevantnih donosilaca odluka u ovoj oblasti.

Ključne reči: ekofeminizam, životna sredina, ekologija, bezbednost, ekološka bezbednost 